\title{
IAMJ
}

INTERNATIONAL

AYURVEDIC

MEDICAL JOURNAL

ISSN: 2320-5091

Impact Factor: 6.719

\section{AN OBSERVATIONAL STUDY TO EVALUATE VASTRARANJANA IN ARTAVAPAREEKSHA}

\author{
Devi S Nair ${ }^{1}$, Nisha Kumari ${ }^{2}$ \\ ${ }^{1}$ Associate Professor, Department of Roga Nidana, K J Institute of Ayurveda and Research, Savli, Vadodara, \\ Gujarat, India \\ ${ }^{2}$ Professor, Department of Roga Nidana, Yenapoya Ayurveda College and Hospital, Mangalore, Karnataka, India
}

Corresponding Author: devisreeletha@gmail.com

https://doi.org/10.46607/iamj0209112021

(Published Online: November 2021)

Open Access

(C) International Ayurvedic Medical Journal, India

Article Received: 06/10//2021 - Peer Reviewed: 27/10/2021 - Accepted for Publication: 29/10/2021

\section{Check for updates}

\begin{abstract}
Objectives: Menstrual problems and infertility are the major problems affecting society nowadays. It can occur due to many reasons namely pathology of Garbhashaya, Artavavaha Dhamani, Dushta Artava etc. For the evaluation of structural abnormalities, various technologies like USG, HSG, Hormonal assay etc. are available. But no methods were developed yet to check the purity of Artava. In this background, the Vastraranjana concept mentioned in the context of Shudha Rakta Lakshana can be considered as a useful tool for diagnosing Artava Dushti. The practicality of this Pareeksha if proved it envisages a new and simple diagnostic tool in Ayurveda. MethodsMenstrual blood samples-stained cotton clothes were washed, and changes were noted. Results- Dushita Artava was found to be causing a stain on the cloth. Conclusion- Changes in the character of Dosha produces Soshana Vidaha Ghanatha etc. of Artava which involve a change in $\mathrm{pH}$, viscosity like elements creating a stain on the cloth.
\end{abstract}

Keywords: Artava Pareeksha, Vastra Ranjana, Menstrual Cycle 


\section{INTRODUCTION}

Pareekshas play a major role in the diagnosis of any disease. They are the tools that give confirmatory knowledge for a better understanding of Vyadhi Avastha. The ancient system of medicines has its investigation methods which are currently not under practice. In classics, Rogi Pareeksha ${ }^{l}$ and Roga Pareeksha ${ }^{2}$ evaluation is done through Pramanas in a very systematic manner. Its assessment gives an idea about the extent of Dosha Dushti, Sanchaya Prakopa Avastha of Dosha, the structural and functional disturbances in Dhatus, the physical and mental strength of the patient and the degree of alteration by disease. The examination of urine, faeces, sputum, vomitus, pulse, tongue, skin, built, nourishment is aware and under practice. But few methods like Tailabindhu Mutra Pareeksha ${ }^{3}$, Artava Pareeksha were considered as unsophisticated and got omitted from current diagnostic methods. Artava one among the Upadhatu takes its origin from the essence of Rasa Dhatu. A wide range of applications is possible for the word Artava, which includes menstrual blood, ovum, hormones etc. If the whole process of menstruation is divided into phases, then menstruation can be taken as Raja Kala where Prakruta Vata dominates and acts as Preraka for its discharge ${ }^{4}$. This is a field where modern systems of diagnosis lack parameters. Contemporary sciences have developed a lot of objective ways of laboratory and radiological examination, but examination of menstrual blood is not yet developed by modern science too. Thus, Artava Pareeksha is a unique concept of our science that should be enlightened to see its practicality. Menstrual problems and infertility can occur due to many reasons namely pathology of Garbhashaya, Artavavaha Dhamani, Dushta Artava etc. This understanding is essential for the selection of treatment too. For the evaluation of structural abnormalities, various technologies are available. But the assessment of Artava Dushti is difficult. But in classics, it is mentioned that no individual is having equality of Tridosha due to variation in Ahara Vihara by everyone even if there are no evident Vikruti Lakshana in them. In this background, Vastra Ranjana concept mentioned in the context of Shudha Rakta Lakshana can be considered as a useful tool for diagnosing Artava Dushti. It is mentioned that Sudha Rakta will never remain as a stain on the cloth after washing but Ashudha does. The practicality of this Pareeksha if proved it envisages a new and simple diagnostic tool in Ayurveda. In the classics, Acharyas mentioned Rtumati Charya and Rajaswala Charya which highlights the importance of lifestyle in changing the quality and quantity of Artava. Only a healthy Artava can produce a healthy child. Dietary habits are fundamental factors that influence human lifestyles and individual quality of life. Menstrual disorders and infertility are more in the present day due to lifestyle changes. Conception and delivery of a healthy child is the aim of society. Thus, women health needs utmost importance. Menstrual blood not vitiated will resemble the blood of rabbits, like the secretion of laccifer lacca, slightly blackish with a peculiar smell ${ }^{5}$ which will be taken by the normal Apana Vayu and evacuated out from the body at an interval of one month. This regular Artava Chakra with Sudha Artava shows that Kshetra and Beeja are healthy. The female reproductive cycle typically ranges from 24-35 days with four phases- the menstrual phase, the preovulatory phase, ovulation, the post-ovulatory phase ${ }^{6}$. Ovary and uterus are two important determining factors, understood as the concept of Kshetra in classics for the regular cycle, hormone balance, healthy pregnancy and labour. The regular menstrual cycle occurs due to morphologic changes in the uterus by hormonal variations. The changes in the luteal or secretory phase are due to progesterone and estrogen secreted by the corpus luteum. In the absence of fertilization, the corpus luteum degenerates and the hormonal level of progesterone and estrogen of luteum falls causing bleeding. Also, the fall of follicle-stimulating hormone and the luteinizing hormone is seen. Normally blood in the menstruation flow is liquefied by a fibrinolytic mechanism thus does not clot. But excessive bleeding expels blood fast before liquefying resulting in clots. In ovular menstruation, there is no corpus luteum formation, thus estrogen of luteum falls resulting in 
bleeding ${ }^{7}$.A highly complex system of blood vessels is involved especially spiral arteries. Fall of ovarian hormone in the blood causes regression shrinkage and atrophy of the endometrium. Both the functional layer and its blood supply by spiral arteries develop together at each menstrual cycle. This progressive coiling of the spiral arteries triggers the vascular mechanism of menstruation. Blood is slightly alkaline with a $\mathrm{pH}$ of 7.4. The acidic environment $\mathrm{pH} 3.8$ 4.5 of the vagina is a natural protective barrier to infections ${ }^{8}$.Vagina maintains the healthy flora by Doderleins bacillus by degradation of glycogen to lactic acid. During menstruation, $\mathrm{pH}$ elevates slightly during the flow of menstrual blood. Blood viscosity is the inherent resistance of blood to flow. Hyper viscosity reduces blood flow causing increased conges- tion. It can damage the blood vessels. Normal menstrual flow can maintain the level of healthy RBC in a higher proportion than older fragile RBC. Disturbance of cycle making more fragile RBC releasing haemoglobin a high molecular weight protein. Hemosiderin is a dark yellow to brown endogenous pigment thus released from haemoglobin which has the ability to stain ${ }^{7}$.

\section{Materials And Methods:}

As an initial study to see the practicality, patients who visited Stree Roga OPD of SDM Hassan were screened and menstrual blood samples were collected by staining sterile cotton white cloth provided. Washing was done with the same detergent after a period of twenty hours of drying. The results were analysed based on their symptoms and investigation reports.

\section{Observations:}

\begin{tabular}{|c|c|c|c|c|c|c|}
\hline $\begin{array}{l}\text { Sl } \\
\text { No }\end{array}$ & Age/Sex & Chief Complaint & $\begin{array}{l}\text { Age of Men- } \\
\text { arche }\end{array}$ & $\begin{array}{l}\text { Duration } \\
\text { /Interval }\end{array}$ & $\begin{array}{l}\text { Features of } \\
\text { Bleeding }\end{array}$ & Result \\
\hline 1 & $35 / \mathrm{F}$ & $\begin{array}{l}\text { Excessive bleeding } 1 \& 1 / 2 \\
\text { month } \\
\text { Scan- moderate nonspecif- } \\
\text { ic inflammation }\end{array}$ & $13 y r s$ & $\begin{array}{l}\text { 10-15 Days/ } \\
1 \& 1 / 2-2 \text { Months }\end{array}$ & $\begin{array}{l}\text { Pain+ } \\
\text { Clot+++ } \\
\text { Foul smell+ } \\
\text { Increased } \\
\text { bleeding }\end{array}$ & Stain remained \\
\hline 2 & $25 / \mathrm{F}$ & $\begin{array}{l}\text { Irregular menstrual cycle- } \\
4 \text { years }\end{array}$ & $12 \mathrm{yrs}$ & $\begin{array}{l}\text { 3-4 Days/ } \\
\text { 2-3 Months }\end{array}$ & $\begin{array}{l}\text { Pain+ } \\
\text { Clot- } \\
\text { Foul smell + }\end{array}$ & No Stain \\
\hline
\end{tabular}




\begin{tabular}{|c|c|c|c|c|c|c|}
\hline 3 & $24 / \mathrm{F}$ & $\begin{array}{l}\text { Irregular menstrual cycle- } \\
6 \text { years }\end{array}$ & $12 \mathrm{yrs}$ & $\begin{array}{l}\text { 2Days/ 2-3 } \\
\text { Months }\end{array}$ & $\begin{array}{l}\text { Pain- } \\
\text { Clot- } \\
\text { Foul Smell- } \\
\text { Decreased } \\
\text { Bleeding }\end{array}$ & No stain \\
\hline 4 & $18 / \mathrm{F}$ & $\begin{array}{l}\text { Severe abdominal pain } \\
\text { during cycles }-1 \text { year } \\
\text { Weight loss- } 14 \mathrm{~kg} \text { in } 5 \\
\text { Months }\end{array}$ & $13 \mathrm{yrs}$ & 5Days / 28 Days & $\begin{array}{l}\text { Pain+++ } \\
\text { Clot++ } \\
\text { Foul Smell+ } \\
\text { Decreased } \\
\text { Bleeding }\end{array}$ & Stain remained \\
\hline 5 & $49 / \mathrm{F}$ & $\begin{array}{l}\text { Irregular menstrual cycle- } \\
2 \text { years }\end{array}$ & $12 \mathrm{yrs}$ & $\begin{array}{l}\text { 5-6Days/ } \\
\text { 3Months }\end{array}$ & $\begin{array}{l}\text { Pain+ } \\
\text { Clot- } \\
\text { Foul Smell- } \\
\text { Increased } \\
\text { Bleeding }\end{array}$ & No Stain \\
\hline 6 & $18 / \mathrm{F}$ & $\begin{array}{l}\text { Increased White dis- } \\
\text { charge- } 10 \text { Months } \\
\text { Itching in vulva- } 3 \text { months }\end{array}$ & $13 \mathrm{yrs}$ & $\begin{array}{l}\text { 4Days/ 26-30 } \\
\text { Days }\end{array}$ & $\begin{array}{l}\text { Pain++ } \\
\text { Clot+ } \\
\text { Foul Smell+ }\end{array}$ & Stain remained \\
\hline
\end{tabular}




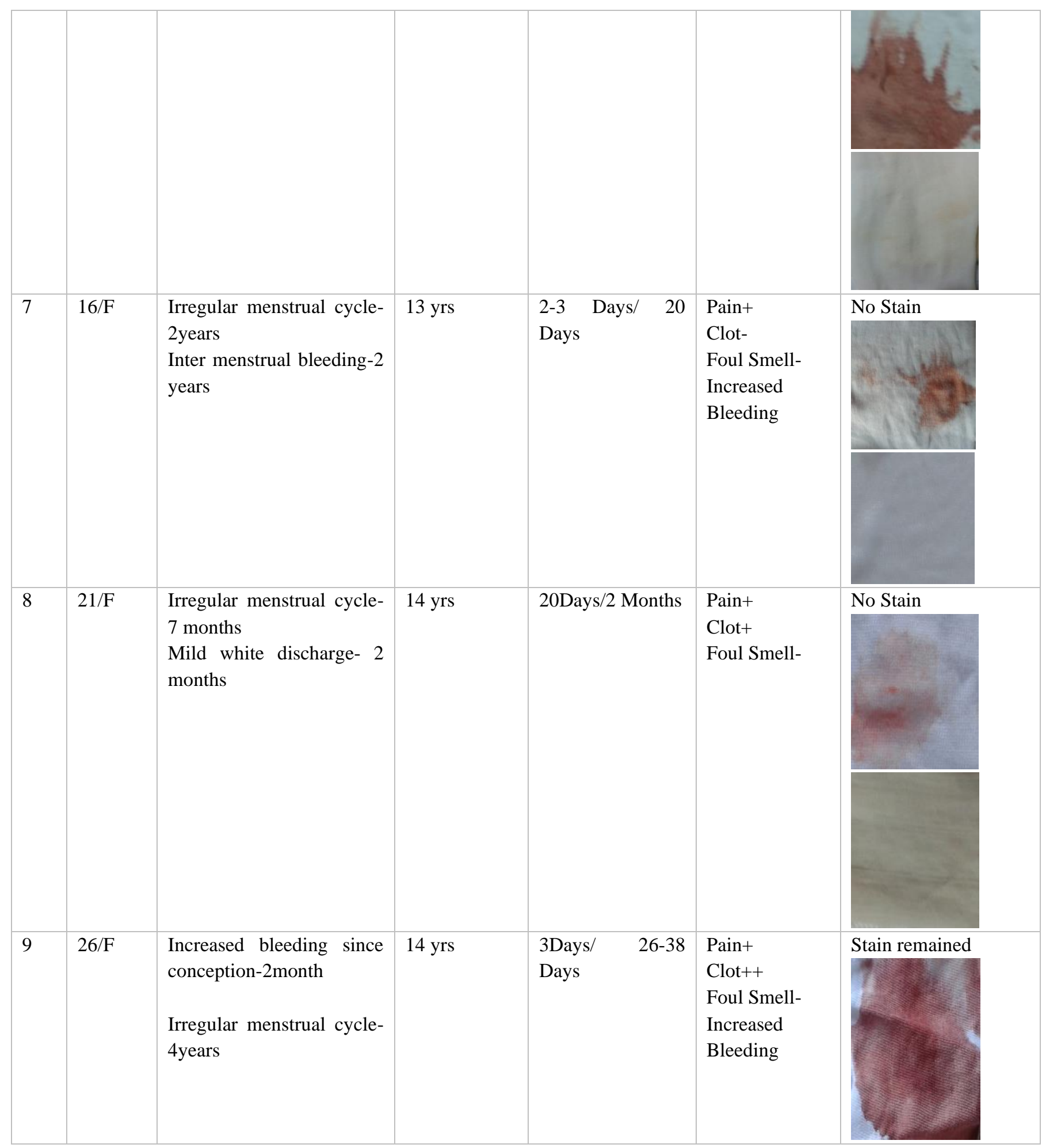




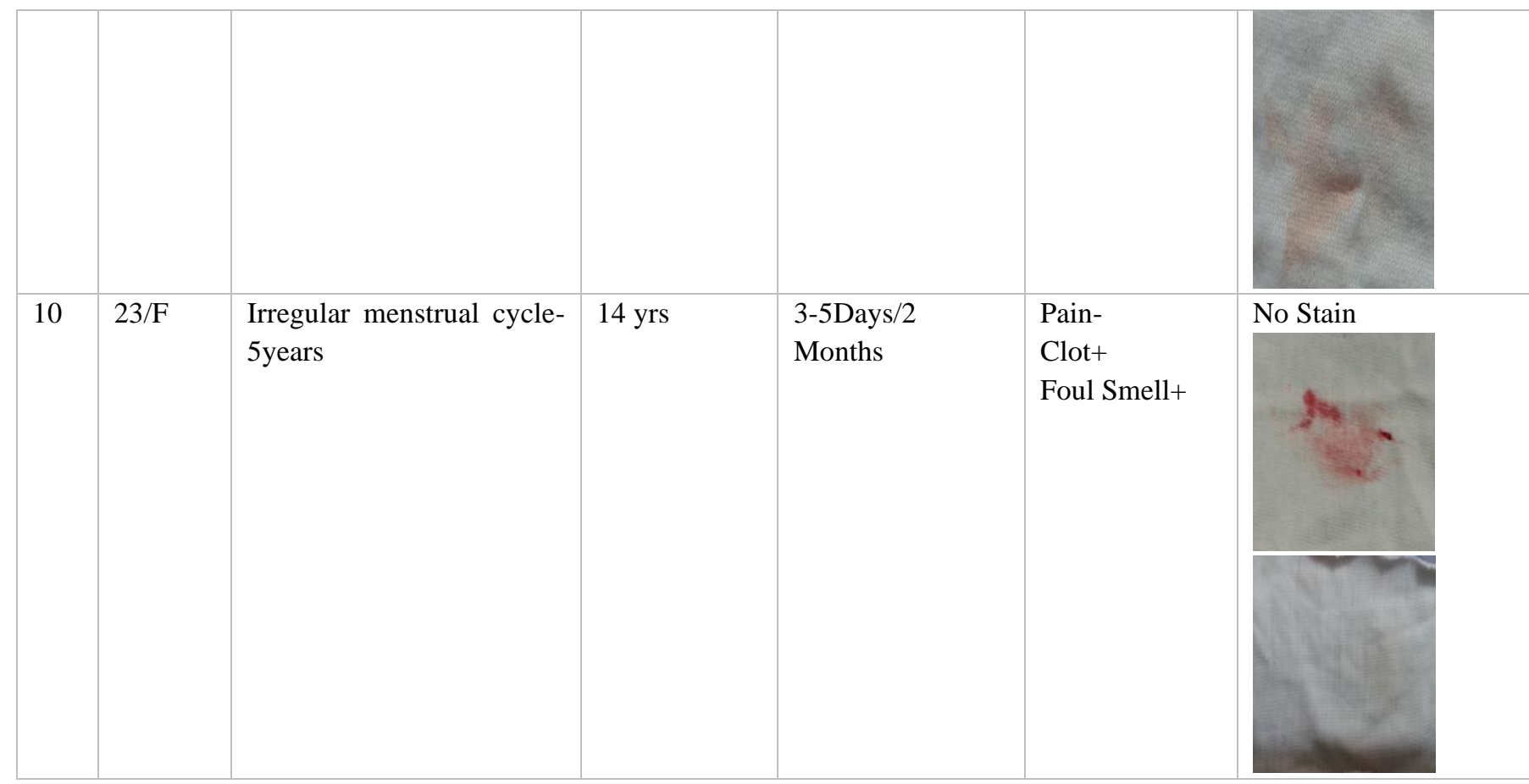

\section{RESULT AND INTERPRETATION}

Artava in its Dooshita Avastha loses its normal characteristics like colour viscosity $\mathrm{pH}$ etc. Considering the cases where stain remained even after washing may be understood on the basis of Doshas

\begin{tabular}{|c|c|c|}
\hline Case1 & $\begin{array}{l}\text { 35/F Excessive bleeding-1\&1/2-month Scan- } \\
\text { moderate nonspecific inflammation Pain+ } \\
\text { Clot+++ Foul smell+ Increased bleeding Stain } \\
\text { remained }\end{array}$ & $\begin{array}{l}\text { shows inflammation of the endometrium, increased bleeding } \\
\text { signifies aggravation of pitta along with drava guna producing } \\
\text { vidaha avastha. This excess pitta increases the Ranjan property } \\
\text { of Artava. }\end{array}$ \\
\hline ase 4 & $\begin{array}{l}\text { 18/F Severe abdominal pain during cycles - } \\
\text { 1year Weight loss- } 14 \mathrm{~kg} \text { in } 5 \text { Months Pain+++ } \\
\text { Clot++ Foul Smell+ Decreased Bleeding Stain } \\
\text { remained }\end{array}$ & $\begin{array}{l}\text { weight loss, severe pain, reduced bleeding signifies the dushti } \\
\text { of vata dosha causing soshana of Artava thus making the stain } \\
\text { dry up fast and is retained. }\end{array}$ \\
\hline Case 6 & $\begin{array}{l}\text { 18/F Increased White discharge- } 10 \text { Months } \\
\text { Itching in vulva- } 3 \text { months Pain++ Clot+ Foul } \\
\text { Smell+ Stain remained }\end{array}$ & $\begin{array}{l}\text { Itching of vulva, white discharge shows kapha dushti increas- } \\
\text { ing the ghanata of Artava, thus abnormal constitution of Artava } \\
\text { produces stain. }\end{array}$ \\
\hline Case 9 & $\begin{array}{l}\text { 26/F Increased bleeding since conception- } \\
\text { 2month Irregular menstrual cycle- 4years } \\
\text { Pain+ Clot++ Foul Smell- Increased Bleed- } \\
\text { ing Stain remained }\end{array}$ & $\begin{array}{l}\text { Assumption can be made as samyoga of shukra and this doosh- } \\
\text { ita Artava would have produced an unhealthy garbha resulting } \\
\text { in garbha srava. }\end{array}$ \\
\hline
\end{tabular}

\section{CONCLUSION}

Thus, changes in the character of Dosha produce Soshana Vidaha, Ghanatha etc. of Artava which involve a change in $\mathrm{pH}$, viscosity like elements creating a stain on the cloth. This is a primitive test where an initial hypothesis is drawn. But further study with large sample size and vast spectrum of observations including other parallel parameters are suggested. 


\section{REFERENCES}

1. Pt. Hari Sadasiva Sastri Paradakara, editor, Ashtanga Hrudaya, Sutra Sthanam, Ayushkameeyam Adhyaya, Chapter 1. Varanasi: Chaukhamba Sanskrit Sansthan, Reprint 2011,14.

2. Vd. Harish Chandra Singh Kushwaha, editor, Charak Samhita of Agnivesha Vol-1, Nidanasthanam, Jwara Nidana Adhyaya, Chapter 1. Varanasi: Chaukhambha Orientalia, Reprint 2011, 511.

3. Bhisagratna Brahmasankar Sastri, editor, Yogaratnakara with Vidyotini commentary of Vaidya Lakshmipati Sastri, $7^{\text {th }}$ ed. Varanasi: Chaukhambha Sanskrit Sansthan, 1999,10.

4. Vaidya Jadavji Trikamji Acharya, editor, Susruta Samhita, Sharir Sthanam, Garbhavakranthi Sareeram Adhyaya, Chapter 3. Varanasi: Chaukhambha Sanskrit Sansthan, Reprint 2010, 351.

5. Vaidya Jadavji Trikamji Acharya, editor, Susruta Samhita, Sharir Sthanam, Sukra Sonitha Sudhi Sareeram Adhyaya, Chapter 2. Varanasi: Chaukhambha Sanskrit Sansthan, Reprint 2010, 346.

6. Gerard J Tortora, Bryan Derrickson, editor, $11^{\text {th }}$ ed, Principles of Anatomy and Physiology, The Female Reproductive Cycle, Chapter 28. United States of America: John Wiley \& Sons, Inc, 1085.

7. Sujit K Chaudhuri, Concise Medical Physiology, $5^{\text {th }}$ ed, Female Reproductive Physiology, Chapter 6.10. Calcutta: New Central Book Agency(P) LTD, 315-6.

8. Dr Hemalatha Kapoorchand, A Comprehensive Treatise on Striroga, Female Infertility, Chapter 6. Varanasi: Chaukhamba Viswa Bharati, 332-4.

\section{Source of Support: Nil \\ Conflict of Interest: None Declared}

How to cite this URL: Devi S Nair \& Nisha Kumari: An Observational Study To Evaluate Vastraranjana In Artavapareeksha. International Ayurvedic Medical Journal \{online\} 2021 \{cited November 2021\} Available from: http://www.iamj.in/posts/images/upload/2652_2658.pdf 